\title{
Incidence of Hallux Valgus in a Partially Shoe-wearing Community
}

\author{
I. B. SHINE,* M.B.
}

Brit. med. F., 1965, 1, 1648-1650

While medical officer to the island of St. Helena in 1960-2 I undertook a survey of the islanders' feet to determine the incidence of hallux valgus among the shoe-wearers and among those who were habitually barefoot.

The island is situated in the centre of the South Atlantic Ocean and has a population of 4,642 , who were descended from European settlers, Chinese labourers, and African slaves. There were 4,000 people over the age of 5 , and it was decided to limit the investigation to those 4,000 ; but time ran out when only $3,515(88 \%)$ had been seen. The age and sex distribution of this sample was the same as the population counted at the last census.

\section{Method}

People were seen in the clinics when they attended for medical treatment, some were seen at home or at work, and the children were seen during routine school examination. The following social data were obtained: age, civil state, number of children, social class, occupation, race, amount of daily exercise, body weight, and smoking habit. They were also asked whether they wore shoes and, if so, how long they had worn them ; and during subsequent examination the amount of plantar keratosis was noted, as it provided a rough check on the reliability of their answers. The feet were inspected by a single observer while the patient stood with the heels and big toes touching, and the angle separating the big toes was recorded. If the toes were separated by less than 10 degrees ( 5 degrees each foot) hallux valgus was considered to be absent; the remainder were placed into three grades of severity, each foot being graded separately. Grade 1 corre-

* Medical Research Council, Population Genetics Research Unit, Headington, Oxford. Formerly Medical Officer to the Government of St. Helena.

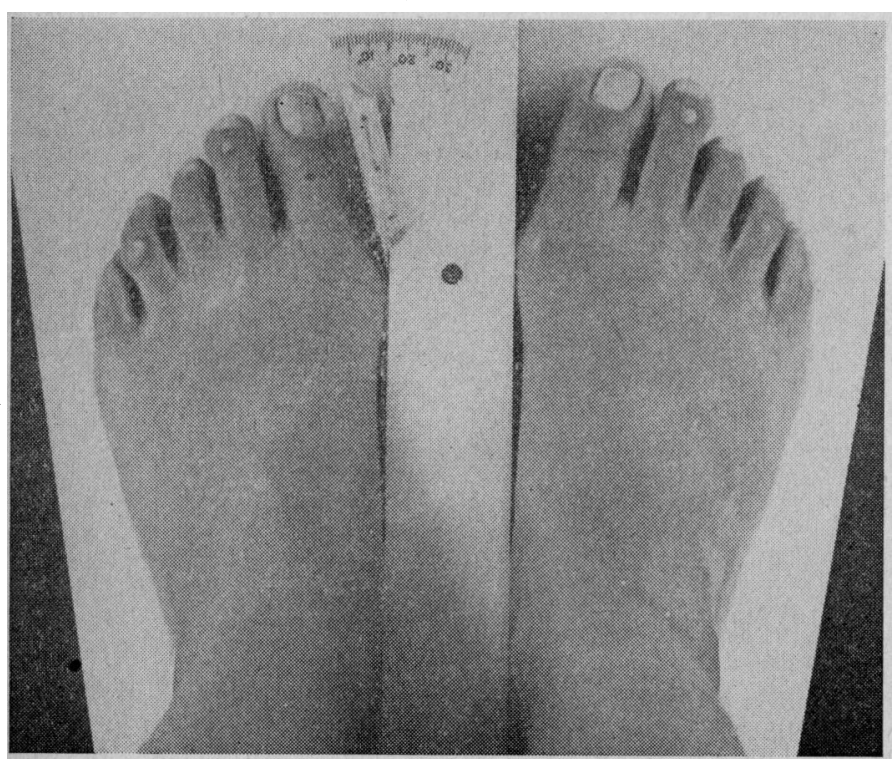

FIG. 1.-Foot-board measurement of a 31-year-old woman who had been barefoot until 17 years of age. sponded to 5-15 degrees deviation per foot; grade 2, 16-25 degrees; and grade 3, 26 degrees and over. To check the validity of this method of grading a $10 \%$ random sample of the population were re-examined without reference to the previous assessment and their feet measured with a Shoe and Allied Trades Research Association's board (Fig. 1). Although there was slight overlap between grade 0 and 1 (Table I) there was no significant difference between the two methods of assessment ; $t=0.016, P>0.9$ (D.F. $=887$ ).

TABLE I.-Comparison Between Visual and Foot-board Grading of Hallux Valgus on Random Sample of 444 People (Feet Scored Separately)

\begin{tabular}{|c|c|c|c|c|c|c|}
\hline \multirow{2}{*}{\multicolumn{2}{|c|}{$\begin{array}{l}\text { Foot-board } \\
\text { Assessment }\end{array}$}} & \multicolumn{4}{|c|}{ Visual Assessment } & \multirow[b]{2}{*}{ Total } \\
\hline & & $\begin{array}{c}\text { Grade } 0 \\
0^{\circ}-\end{array}$ & $\underset{6^{\circ}-}{\text { Grade } 1}$ & $\begin{array}{c}\text { Grade } 2 \\
16^{\circ}-\end{array}$ & $\begin{array}{c}\text { Grade } 3 \\
26^{\circ}+\end{array}$ & \\
\hline $\begin{array}{l}\text { Grade } 0,0^{\circ}- \\
\text { Grade 1, } 6^{\circ}- \\
\text { Grade } 2,16^{\circ}- \\
\text { Grade 3, 26 }\end{array}$ & $\begin{array}{l}\cdots \\
\cdots \\
\cdots\end{array}$ & $\begin{array}{r}570 \\
96 \\
2 \\
-\end{array}$ & $\begin{array}{l}40 \\
85 \\
12 \\
\end{array}$ & $\begin{array}{r}\overline{33} \\
26 \\
7\end{array}$ & $\frac{-}{7}$ & $\begin{array}{r}610 \\
214 \\
47 \\
17\end{array}$ \\
\hline Total & .. & 668 & 137 & 66 & 17 & 888 \\
\hline
\end{tabular}

\section{Type of Footwear}

Some people bought shoes by mail order from South Africa or Great Britain, and others bought them from the local shops ; in either case only a limited range of sizes in a single fitting were available. The commonest style worn by either sex was a flat-heeled, round-toed, laced shoe; but over the last five years young women have tended to wear high-heeled shoes with pointed toes, and some men have tended to wear open sandals with a thong between the first and second toes. As the average wage on St. Helena is under $£ 3$ a week it is not surprising that $54 \%$ of the population surveyed preferred to be barefoot, yet reserving one pair of shoes for church service, a visit to the doctor, or for holidays.

If asked the reason why they started to wear shoes people would say that it was necessary for their job as teachers, Government clerks, or domestic servants ; or for the protection of their feet ; or for health reasons, as it was widely believed that wearing shoes was a prophylactic against a variety of diseases. Socks were not aways worn with shoes, and stretch socks were not available.

\section{Results}

The population was divided into two main groups, the barefoot and the shoe-wearers, and the latter were subdivided into groups that had been wearing shoes for varying lengths of time. The mean angle of hallux deviation in each group was calculated (Table II), and, as there was slight overlap between group 0 and 1, the proportion of each group with hallux deviation greater than 15 degrees was adopted as a more reliable standard (Fig. 2). Both indices show a linear rise of hallux valgus with increase in the number of years that shoes were worn. 
A multiple regression analysis of body weight, occupation, and the other social factors mentioned above failed to show any association with hallux valgus. Shoe-wearing, however, showed a highly significant association: $b=0.01685 \pm 0.0029$, $\mathrm{P}<0.001$ for men; and $\mathrm{b}=0.04266 \pm 0.0057, \mathrm{P}<0.001$ for women.

TABLE II.-Mean Hallux Valgus Angle (in Degrees) for the Barefoot and Various Groups of Shoe-wearers. Data from 1,852 Males and 1,663 Females

\begin{tabular}{|c|c|c|c|c|c|c|}
\hline \multirow[b]{2}{*}{ Shod } & \multicolumn{3}{|c|}{ Males } & \multicolumn{3}{|c|}{ Females } \\
\hline & $\begin{array}{l}\text { No. of } \\
\text { People }\end{array}$ & $\begin{array}{c}\text { Mean } \\
\text { Hadlux } \\
\text { Angle }\end{array}$ & S.D. of & $\begin{array}{l}\text { No. of } \\
\text { People }\end{array}$ & $\begin{array}{c}\text { Mean } \\
\text { Hallux } \\
\text { Angle }\end{array}$ & $\begin{array}{l}\text { S.D. of } \\
\text { Mean }\end{array}$ \\
\hline $\begin{array}{c}<10 \text { years } \\
10-", \\
20-", \\
30-" \\
40-" \\
50-" \\
60+" \\
\end{array}$ & $\begin{array}{r}338 \\
111 \\
94 \\
66 \\
46 \\
32 \\
24\end{array}$ & $\begin{array}{l}2 \cdot 6^{\circ} \\
3 \cdot 3^{\circ} \\
4 \cdot 7^{\circ} \\
4 \cdot 1^{\circ} \\
4 \cdot 6^{\circ} \\
6 \cdot 2^{\circ} \\
6 \cdot 2^{\circ}\end{array}$ & $\begin{array}{l}5 \cdot 4^{\circ} \\
6 \cdot 2^{\circ} \\
7 \cdot 4^{\circ} \\
6 \cdot 6^{\circ} \\
8 \cdot 4^{\circ} \\
8 \cdot 7^{\circ} \\
7 \cdot 7^{\circ}\end{array}$ & $\begin{array}{r}353 \\
133 \\
110 \\
113 \\
78 \\
60 \\
56\end{array}$ & $\begin{array}{r}3.6^{\circ} \\
5.5^{\circ} \\
6.2^{\circ} \\
9.3^{\circ} \\
9.6^{\circ} \\
11.2^{\circ} \\
13.4^{\circ}\end{array}$ & $\begin{array}{r}6.3^{\circ} \\
6.8^{\circ} \\
8.3^{\circ} \\
8.4^{\circ} \\
9.5^{\circ} \\
9 \cdot 8^{\circ} \\
10.8^{\circ}\end{array}$ \\
\hline Barefoot & 1,141 & $0.8^{\circ}$ & $3 \cdot 3^{\circ}$ & 760 & $0.9^{\circ}$ & $3.6^{\circ}$ \\
\hline
\end{tabular}

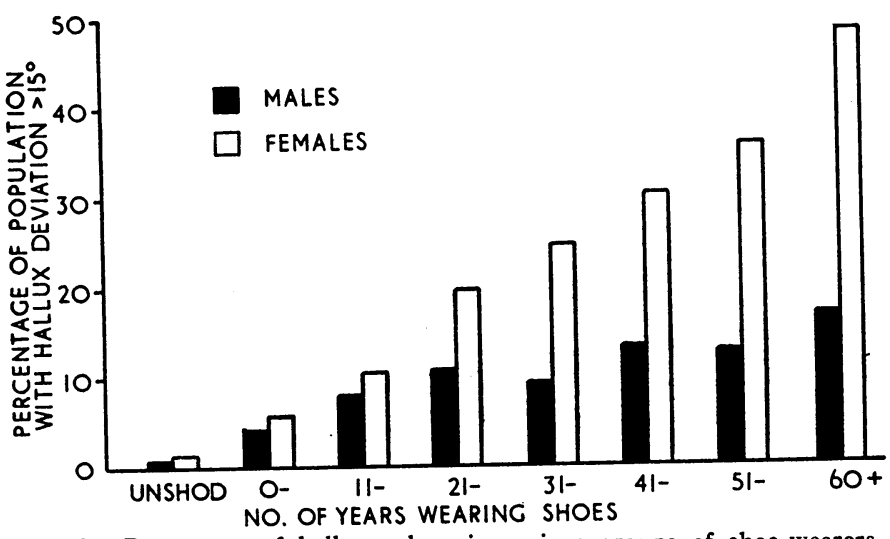

FIG. 2.-Percentage of hallux valgus in various groups of shoe-wearers. Data from 1,852 males and 1,663 females.

\section{Discussion}

Nothing is known of the incidence of hallux valgus in the past when shoes and shoe-wearing habits differed from the present. It was not described by the classical authors (Camper, 1781), and its population incidence was not fully established until 1953 (Dykes et al., 1953). Raphael portrays St. John in "The Coronation of the Virgin," 1502, with 30 degrees of hallux valgus, which was probably the earliest recorded observation of this disease; but its incidence cannot be inferred from the evidence of sculpture and painting, as even contemporary artists portray the big toe undistorted; Picasso's “The Tragedy," 1903, is an exception.

Nor is there much useful evidence from existing barefoot societies, as the pre-war surveys did not use measurements. Engle and Morton (1931) found no hallux valgus among the Congolese; Wells (1931) found " normal hallux valgus" more commonly among the Bushmen and Bantu than among Europeans, but he was referring to a different phenomenon. James (1939) found a straight inner border of the feet of the Solomon Islanders. Barnicot and Hardy (1955) measured the feet of 652 Nigerians with a pedograph and compared them with 134 local Europeans; they found the mean angle of the barefoot Nigerians was less than 2 degrees (although about $3 \%$ had a deviation greater than 15 degrees) and the mean angle of the European men was 6.9 degrees and the women 11 degrees. Kalcev (1963) found a similar incidence among the Malagasy. Lam Sim-Fook and Hodgson (1958) examined 200 Chinese in Hong Kong and found hallux valgus in $1.9 \%$ of the barefoot and in $30 \%$ of the shoe-wearers. Emslie (1939) examined the feet of barefoot London toddlers and found that they had normal feet, unlike the shoe-wearers, who frequently showed deflection of the terminal phalanx of the big toe.

This study shows that hallux deviation greater than 15 degrees was present in $2 \%$ of the barefoot, and in $16 \%$ of the men and $48 \%$ of the women who had worn shoes for 60 years. As the rise in incidence is linear, and as it cannot be attributed to age, social class, occupation, or exercise habits, it is likely that the increase is a direct effect of wearing shoes. This is supported by Haines and McDougall's (1954) demonstration that most forms of shoes constrict the toes; and by the demonstration by Chinese women that constricting forces will produce anatomically deformed feet. It has been suggested (B.M.F., 1953) that hallux valgus is more prone to develop if constricting shoes are worn in childhood or adolescence; but the present survey does not support this view. Barefoot St. Helenian women in their fourth decade had a mean hallux angle of 1 degree, and the barefooted women in their fifth decade had a mean hallux angle of 1.2 degrees. But the women in their fifth decade who had worn shoes for an average of four years had a mean angle of 5 degrees (Table III). This increase is seen in both sexes at all ages after wearing shoes for only four years and necessitates the conclusion that hallux valgus is as likely to develop at 40 as at 10 years of age.

A different sex incidence of hallux valgus has often been noted, and as it is present at an age when both sexes wear similar shoes it might seem that shoes may not therefore be an important causal factor. The St. Helenians also show a different sex incidence, and, as both sexes wear a similar shoe, style alone is unlikely to be responsible. Nor are occupational or exercise differences responsible, because they were not found to be associated with hallux valgus in this survey. As the difference in sex incidence was not seen in the unshod it suggests an unfavourable interaction between female genotype and shoes. As hallux valgus was absent in some families who wore shoes and was present in others who did not, it was apparent that there was an additional genetical contribution, but no simple pattern of inheritance was obvious. It is hoped that further analysis of the family data will clarify this. Even if genotype is the most important causal factor, in practice it is irrelevant, as it is impossible to modify one's inheritance but easy to improve footwear.

TABle III.-Mean Hallux Valgus Angle (in Degrees) by Age-group and Sex, for Barefoot and Shoe-wearers. Data from 3,006 Islanders over 10 Years Old

\begin{tabular}{|c|c|c|c|c|c|c|c|c|c|c|c|c|c|c|c|c|c|c|}
\hline \multirow{4}{*}{$\begin{array}{c}\text { Age- } \\
\text { group } \\
\text { (Years) }\end{array}$} & \multicolumn{9}{|c|}{ Males } & \multicolumn{9}{|c|}{ Females } \\
\hline & \multirow{2}{*}{\multicolumn{3}{|c|}{ Barefoot }} & \multicolumn{6}{|c|}{ Shoe-wearers } & \multirow{2}{*}{\multicolumn{3}{|c|}{ Barefoot }} & \multicolumn{6}{|c|}{ Shoe-wearers } \\
\hline & & & & \multicolumn{3}{|c|}{ 1-8 Years } & \multicolumn{3}{|c|}{$1-60$ Years } & & & & \multicolumn{3}{|c|}{ 1-8 Years } & \multicolumn{3}{|c|}{ 1-60 Years } \\
\hline & $\begin{array}{l}\text { No. } \\
\text { of } \\
\text { Feet }\end{array}$ & $\begin{array}{c}\text { Mean } \\
\text { Angle } \\
\text { (Degrees) }\end{array}$ & S.D. & $\begin{array}{l}\text { No. } \\
\text { of } \\
\text { Feet }\end{array}$ & $\begin{array}{c}\text { Mean } \\
\text { Angle } \\
\text { (Degrees) } \\
\end{array}$ & S.D. & $\begin{array}{c}\text { No. } \\
\text { of } \\
\text { Feet }\end{array}$ & $\begin{array}{c}\text { Mean } \\
\text { Angle } \\
\text { (Degrees) }\end{array}$ & S.D. & $\begin{array}{c}\text { No. } \\
\text { of } \\
\text { Feet }\end{array}$ & $\begin{array}{c}\text { Mean } \\
\text { Angle } \\
\text { (Degrees) }\end{array}$ & S.D. & $\begin{array}{c}\text { No. } \\
\text { of } \\
\text { Feet }\end{array}$ & $\begin{array}{c}\text { Mean } \\
\text { Angle } \\
\text { (Degrees) }\end{array}$ & S.D. & $\begin{array}{c}\text { No. } \\
\text { of } \\
\text { Feet }\end{array}$ & $\begin{array}{c}\text { Mean } \\
\text { Angle } \\
\text { (Degrees) } \\
\end{array}$ & S.D. \\
\hline $\begin{array}{l}10- \\
20- \\
30- \\
40- \\
50- \\
60+\end{array}$ & $\begin{array}{l}928 \\
254 \\
144 \\
138 \\
156 \\
150\end{array}$ & $\begin{array}{l}0.6 \\
1.3 \\
1.9 \\
2.2 \\
1.4 \\
2.7\end{array}$ & $\begin{array}{l}2 \cdot 8 \\
3.6 \\
4.3 \\
5.9 \\
4 \cdot 2 \\
6.8\end{array}$ & $\begin{array}{r}204 \\
224 \\
70 \\
60 \\
58 \\
22\end{array}$ & $\begin{array}{l}2 \cdot 0 \\
2 \cdot 6 \\
3.3 \\
2.5 \\
3.3 \\
2 \cdot 7\end{array}$ & $\begin{array}{l}5 \cdot 2 \\
5 \cdot 3 \\
6 \cdot 3 \\
5 \cdot 1 \\
6 \cdot 0 \\
5 \cdot 5\end{array}$ & $\begin{array}{l}232 \\
290 \\
188 \\
288 \\
246 \\
217\end{array}$ & $\begin{array}{l}2 \cdot 1 \\
2 \cdot 6 \\
3 \cdot 6 \\
3 \cdot 4 \\
3 \cdot 4 \\
5 \cdot 8\end{array}$ & $\begin{array}{r}11 \cdot 6 \\
5.5 \\
6 \cdot 6 \\
6 \cdot 3 \\
6.5 \\
8 \cdot 4\end{array}$ & $\begin{array}{r}606 \\
116 \\
134 \\
50 \\
64 \\
60\end{array}$ & $\begin{array}{l}1 \cdot 0 \\
2 \cdot 1 \\
1.0 \\
1.2 \\
1.9 \\
3 \cdot 0\end{array}$ & $\begin{array}{l}3 \cdot 6 \\
5 \cdot 2 \\
3 \cdot 3 \\
5 \cdot 2 \\
5 \cdot 9 \\
5 \cdot 6\end{array}$ & $\begin{array}{r}266 \\
146 \\
68 \\
62 \\
38 \\
16\end{array}$ & $\begin{array}{l}3.2 \\
4.9 \\
3.7 \\
5.0 \\
5.5 \\
1.9\end{array}$ & $\begin{array}{l}5 \cdot 8 \\
6 \cdot 7 \\
6 \cdot 2 \\
7 \cdot 6 \\
7 \cdot 2 \\
4 \cdot 0\end{array}$ & $\begin{array}{l}326 \\
274 \\
264 \\
272 \\
246 \\
368\end{array}$ & $\begin{array}{r}3 \cdot 8 \\
5 \cdot 0 \\
4 \cdot 9 \\
6 \cdot 9 \\
8 \cdot 6 \\
10 \cdot 5\end{array}$ & $\begin{array}{r}6 \cdot 2 \\
6.5 \\
6.9 \\
8 \cdot 5 \\
9 \cdot 0 \\
10.5\end{array}$ \\
\hline
\end{tabular}




\section{Summary}

The natural history of the unshod foot was studied on the island of St. Helena, where half the islanders have gradually adopted shoe-wearing over the past few decades. Hallux valgus was found in under $2 \%$ of the unshod and in $16 \%$ of the men and $48 \%$ of the women who had worn shoes for more than 60 years.

It is a pleasure to thank Dr. C. E. Hollman, Dr. A. C. Stevenson, and Professor M. L. Rosenheim for their encouragement and advice ; Mrs. M. Parke, Miss R. A. Ash, Mr. A. Barr, and Mr. J. Scott for their statistical help; the St. Helenians for their friendly co-operation ; and Oxford University Department of Biometry for the use of their computer.

\section{REFERENCES}

Barnicot, N. A., and Hardy, R. H. (1955). 7. Anat. (Lond.), 89, 355. Brit. med. f., 1953, 2, 772 .

Camper, P."(1781). Dissertation sur la Meilleure Forme des Souliers. Amsterdam. Translation by Dowie (1861).

Dykes, R. M., Grundy, F., and Lee, H. B. (1952). Med. Offr, 87, 223.

Emslie, M. (1939). Lancet, 2, 1260.

Engle, E. T., and Morton, D. J. (1931). F. Bone ft Surg., 13, 311.

Haines, R. W., and McDougall, A. (1954). Lancet, 2, 1308 .

James, C. S. (1939). Ibid., 2, 1390

Kalcev, B. (1963). East Africa med. 7., 40, 2, 47.

Lam Sim-Fook and Hodgson, A. R. (1958). 7. Bone 7t Surg., 40A, 1058

Wells, L. H. (1931). Amer. Э. phys. Anthrop., 15, 185.

\title{
Haemoglobin H Disease with Occlusion of Right Anterior Cerebral Artery, Xanthochromia, and Pleocytosis of C.S.F.
}

\author{
G. A. RANSOME, * F.R.C.P. ; J. L. DA COSTA,* M.R.C.P.ED., M.R.C.P.GLASG.
}

Brit. med. F., 1965, 1, 1650-1651

At present there is perhaps a tendency to minimize the clinical localization in connexion with the individual cerebral artery involved. This is largely due to the conception of remote arterial disease producing symptoms resembling thrombosis in the territories of cerebral arteries proper, and also because there is considerable overlap in the recognized syndromes. More attention is now focused on assessing the modalities involved and thereby making an anatomical diagnosis, and if it becomes necessary to recognize an individual vessel angiography will demonstrate it far more clearly than inspired guesswork.

A great deal of time and thought as well as post-mortem evidence have been spent in the past in reviewing the syndromes of the individual cerebral arterial occlusions.

The result of occlusion of the main trunk of the anterior cerebral artery depends very much on the size of the anterior communicating artery. If this is large and patent, then occlusion of the main trunk of the anterior cerebral artery will either produce no ill effects or give rise to a syndrome similar to that following thrombosis of Huebner's artery. If collateral circulation is poor the resulting syndrome is much more serious (Kiloh, 1953).

The following case is of considerable interest from the diagnostic point of view because it occurred in a patient suffering from haemoglobin $\mathrm{H}$ disease and because of the subsequent remarkable recovery.

\section{Case History}

A pale, sallow, pigmented Chinese carpenter was admitted to hospital with organic dementia and Jacksonian epilepsy. The story was that he was in his usual health until one week before admission, when he became unwell and febrile, for which he took Chinese (herbal) medicine. The following afternoon he vomited after the midday meal, and about the same time started to have recurrent Jacksonian attacks originating at the left corner of the mouth and spreading to involve the left side of the face and the left arm and hand. These attacks occurred several times a day and lasted for about a minute, but he did not lose consciousness and he continued going to work for four days. The attacks then became more frequent, so he stayed at home and at the end of the week was persuaded to come to hospital. At no stage of the illness did he have any headache or visual disturbances.
On admission he was found to have a low-grade fever and was obviously anaemic. He had a sallow, expressionless face, and melanotic pigment was noticed over the limbs, lips, and buccal mucosa. He was able to walk and talk but was extremely stupid. He was apathetic, drowsy, very slow in answering questions, and showed perseveration. From time to time Jacksonian attacks were observed; each lasted 45 seconds, and they were identical. They occurred approximately once every 15 minutes.

Neurological examination demonstrated no neck rigidity. The pupils, fundi, and visual fields were normal, although visual attention was poor. There was minimal paresis involving the left arm and face. The plantar reflexes were flexor. No sensory loss was demonstrated nor any agnosia. Double Wartenberg responses were present in both upper extremities. There was a strongly positive Rissl reflex, and grasping reflexes were present in both hands and the left foot. He had also passed urine in bed.

To sum up, the picture presented was one of organic dementia resembling advanced G.P.I. or pellagra.

At lumbar puncture on the day of admission the C.S.F. pressure was normal, but the fluid was xanthochromic and slightly turbid. The cell count was 230/c.mm., mainly lymphocytes; protein $300 \mathrm{mg} . / 100 \mathrm{ml}$, globulin was present, and the sugar $71 \mathrm{mg} . / 100$ $\mathrm{ml}$. Smear and culture were negative for organisms.

The other pathological findings are discussed below.

\section{Progress}

Within two days of admission and without specific treatment the patient began to improve rapidly. He soon became more alert and was able to answer questions quickly and rationally. No further fits occurred. Within three to four days the Rissl reflex and Wartenberg and grasp reflexes disappeared and the leftsided facial and upper-limb weakness also disappeared, and at the time of the arteriogram he was virtually well. In retrospect, he did not complain of headache and was unaware of his previous disabilities.

A second lumbar puncture three days after the first still showed faint xanthochromia, with a cell count of $70 / \mathrm{c} . \mathrm{mm}$. and a protein of $100 \mathrm{mg} . / 100 \mathrm{ml}$. It was decided to go on with the arteriogram, and this showed an occlusion of the main trunk of the right anterior cerebral artery proximal to the anterior communicating artery, with a good cross-flow from the left anterior cerebral artery through the anterior communicating artery.

\footnotetext{
* Department of Medicine, General Hospital, Singapore.
} 